\title{
Local Government Tasks in Managing Migrations in the Czech Republic and Poland
}

\section{Marcin Princ* \\ David Kryska*}

\author{
http://doi.org/10.31297/hkju.20.2.4 \\ UDK 341.43:352(438:437.1) \\ 351.756(438:437.1) \\ Review scientific paper / pregledni znanstveni rad \\ Received / primljeno: $\quad$ 20.11.2019. \\ Accepted / prihvaćeno: 10. 4. 2020.
}

The article provides an analysis of the tasks of local self-government units discussed in light of the migration process. The authors compare the legal framework in Poland and the Czech Republic primarily in relation to the tasks of communes. The scope of the research includes an explanation of issues such as the legal status of a foreigner, the tasks of local government entities, and who is the member of a local self-government community. The article also

"Marcin Princ, PhD, Assistant Professor at the Faculty of Law and Administration, Adam Mickiewicz University in Poznań, Poland (izvanredni profesor, Fakultet prava i javne uprave, Sveučilište Adam Mickiewicz, Poznan, Poljska, e-mail: m.princ@amu.edu.pl)

ORCID ID: 0000-0002-3727-7455

** David Kryska, PhD, Senior Lecturer, Faculty of Law, Charles University, Prague, the Czech Republic (viši predavač, Pravni fakultet, Karlovo sveučilište, Prag, Češka, e-mail: kryska@prf.cuni.cz)

ORCID ID: 0000-0002-0083-7498. 
contains examples of actions undertaken for the benefit of foreigners based on current legal grounds. The research is mainly based on two methods: the legalistic and the comparative. The considerations revolve around the main thesis that solving the "wicked problems" category can only be achieved through the participation and joint responsibility of the local self-government and central government. With respect to the content of the European Charter of Local Self-Government, public responsibilities are generally to be exercised, in preference, by those authorities, which are closest to the citizen. Hence, this postulate primarily concerns communes.

Keywords: migration, foreigners, local self-government, inhabitants, citizens

\section{Introduction}

Contemporary public administration is still struggling with current challenges, some of which can be classified into the so-called wicked problems category. One such problem, which by its nature is difficult to solve due to the changing conditions, complexity, and conflict of various values is migration. The contradiction lies in the fact that treaty obligations and declared values collide with social attitudes and the voices of politicians. It is not necessary to convince anyone that migration is a difficult problem, especially in light of the migration crisis (Savino, 2017, p. 13). The strong interest of scientists in this subject has recently been the basis for a discussion of representatives of many disciplines (Koprić, Lalić Novak \& Vukojičić Tomić, 2019, p. 26). Undoubtedly, one of the wicked problems is migration, which obviously has its local consequences; but while the solution to the problem of migration exceeds the capabilities of local authorities due to its very nature, these same authorities, due to the nature of the consequences, should be more involved in solving the problem (Koprić, 2018, p. 18; Giljević \& Lalić Novak, 2018, p. 373).

The subject of the analysis included in this study are the tasks of local self-government units, which will be discussed in light of the migration process. However, it must be added that the study applies to the immigration of foreigners, considered within the broader concept of the migration process. The authors' intention is that the article should be rec- 
ognised within the context of two disciplines: administrative law science and the science of administration. It is worth emphasising that both in the Czech Republic and in Poland, in line with the collective concept of the definition of administrative sciences, there are three to be considered: administrative law science, the science of administration, and administrative policy (Leoński, 2004, p. 15; Sládeček, 2019, p. 47). The last one mentioned is outside the scope of interest of this article. The effort of the authors is focused on the normative aspect of local self-government units' tasks in the field of migration. Other related issues, such as the needs of immigrants and the integration of government policy are not the subject of the study.

The main aim of the study is to verify the thesis that solving the wicked problems category can only be achieved with the participation and joint responsibility of the local self-government. Hence, the postulate to further delegate tasks to local self-government units has been raised. Primarily, the questions arise if a self-governing community consists of only citizens or of citizens and migrants as well, and what the role of local self-government units is in the field of immigration: granting international protection and the integration of all migrants residing within the local self-government units.

The impetus to undertake work in this area was also the result of a prima facie observation that in both the Czech Republic and Poland, acts regulating the functioning of self-government units do not entrust tasks to local self-governments in the field of migration. Traditionally, matters concerning foreigners are reserved for the state (government). Incidentally, the Austrian tradition (historically common to both of the observed countries), where some of the tasks were also carried out by bodies of local self-government (e.g., homeland relations - Ger. Heimatverbältnisse, ${ }^{1}$ police expulsion-Ger. Abschaffung ${ }^{2}$ ), should be mentioned here. It should be emphasized that in the last few years, a specific tendency has been observed in the Czech Republic and in Poland manifesting itself in the aspirations of big cities in particular to set standards for the observance of human rights. This trend is also addressed in the article. The authors'

${ }^{1}$ Gesetz vom 3. Dezember 1863 betreffend die Regelung der Heimatverhältnisse. In: Reichs-Gesetz-Blatt für das Kaiserthum Österreich, Jg. 1863, Stück XLIII., No. 105, pp. 368-376.

${ }^{2}$ See e.g. Pražák, J. Rakouské právo správní. Část’ druhá. Nástin zvláštní části práva správního. Prague: Jednota právnická, 1906, pp. 80-82. 
intention is to conduct research primarily using a comparative law method, consisting of comparing legal systems and individual legal institutions.

\section{The Legal Framework}

The Czech Republic and Poland are unitary states, but the constitution provides for the decentralisation of power. The constitutions have also been designed in such a way as to ensure the balance and harmony of power (Suchocka, 1998, p. 146). "Local self-government" is not a part of the state authority from which it is separated and from which it is also protected in some cases (Filip \& Svatoň, 2011). According to the Constitution, the Czech Republic is a unitary state, and state authority is exercised by the people through legislative, executive, and judicial bodies. The state may intervene in the affairs of a local self-government entity only if such is required for the protection of the law and only in the manner provided for by statute. Although the Constitution of the Czech Republic guarantees the right of autonomous territorial units to self-government, it does not specify in any way what constitutes the content of this right. ${ }^{3}$

In contrast, the Constitution of the Republic of Poland provides that the territorial system of the Republic of Poland ensures the decentralisation of public power, and local self-government participates in exercising public authority. The substantial part of public duties in which local self-government is empowered to discharge by statute is undertaken in its own name and under its own responsibility. The principle of decentralisation is described in the literature as one of the characteristic elements of the modern state of law (Ziemski \& Karciarz, 2019, p. 131). Local self-government is a public law corporation, and its inhabitants form a self-governing community under the law. They are therefore one of the main pillars of the community outside the territory. Similar, but not identical formulations can be found in the Constitution of the Czech Republic. Local self-government units are territorial communities of citizens with the right to self-government. Local self-government units are public law

${ }^{3}$ In a judgement of the Constitutional Court, it was stated that the guarantee of the right to self-government of local self-government units is "laconic" according to the Czech Constitution, while on the other hand pointing out that the Constitution in a general way expressed the right to self-government which certainly cannot be emptied by the legislative power. See the judgment of the Constitutional Court of 05.02.2003, ref. no. Pl.ÚS 34/02, NALUS. 
corporations that may hold their own property and manage their affairs on the basis of their own budget.

In Poland, it is assumed that the basic unit of local self-government is a commune, and other units of regional and/or local government are specified by statute. The commune performs all tasks of local self-government not reserved for other units of local self-government. The Constitution states that first of all, the activity of local self-government consists of performing public tasks (own tasks), as well as delegated tasks in justified cases. Such regulations are also found in the Czech Constitution. The Czech Republic is subdivided into communes, which are the basic local self-government units, and into regions, which are the higher local self-government units. Communes always form part of a higher self-governing region. It may be concluded from these constitutional regulations that in the Czech Republic, there is no (and without constitutional change cannot be) any other type or level of territorial self-government units outside communes and regions (Kopecký, 2010).

The Constitution of the Republic of Poland does not set a precise limit on what is a government task and what is a task of local self-government. Pursuant to Art. 163 of the Constitution of the Republic of Poland, the local self-government shall perform public tasks not reserved by the Constitution or statutes to the bodies of other public authorities. On the other hand, the Council of Ministers shall conduct the internal affairs and foreign policy of the Republic of Poland, and its competencies include the affairs of state not reserved to other state authorities or local self-governments. Similarly, the Constitution of the Czech Republic does not directly regulate which tasks should be performed by the state through its bodies or local self-government entities, or which tasks should be delegated to local self-government units. In this respect, one can see a certain freedom of interpretation. It is also worth noting that neither the Czech nor the Polish Constitutions contain such formulations as, for example, those contained in the Italian Constitution. As stated in Art. 117 of the Constitution of the Italian Republic, "Legislative powers shall be vested in the State and the Regions in compliance with the Constitution and with the constraints deriving from EU legislation and international obligations. The State has exclusive legislative powers in the following matters: a) foreign policy and international relations of the State; relations between the State and the European Union; right of asylum and legal status of nonEU citizens; b) immigration (...) i) citizenship, civil status, and register offices". 
The most important issues concerning the system, organization, and tasks of local self-government units in Poland are contained in four acts: the Act of March 8, 1990, on Commune Self-Government, ${ }^{4}$ the Act of June 5 , 1998, on Poviat Self-Government, ${ }^{5}$ the Act of June 5, 1998, on Voivodeship Self-Government, ${ }^{6}$ and the Act of March 15, 2002, on the System of the Capital City of Warsaw ${ }^{7}$. These issues are regulated in the Czech Republic by the Act on Communes, ${ }^{8}$ the Act on Regions ${ }^{9}$, and the Act on the Capital City of Prague. ${ }^{10}$ Further on in the article, the considerations will focus on commune tasks with respect to the existence of these units at the local level in both countries. In the Czech Republic, poviats are not part of the local self-government. The Czech Republic is divided into communes and regions, with the capital city of Prague occupying a special place, being both a commune (city) and a region.

\section{Local Self-Government Scope of Affairs - Comparative Law Analysis}

The power of local self-government is manifested in the right (ability) of the community to independently decide on its own matters and to administer these matters (Filip \& Svatoň, 2011, p. 308). What one might call independence in administration (Lisowski, 2019, p. 89-104). Local self-government tasks are aimed at satisfying the needs of citizens. They are performed independently and by taking responsibility for them. The above description reflects the understanding of the self-government's own tasks, which occur next to the delegated tasks. Such a division can be found in all the course books of administrative law (Leoński, Hauser

${ }^{4}$ Consolidated text, Journal of Laws of 2019, item 506, as amended.

5 Consolidated text, Journal of Laws of 2019, item 511, as amended. The Poviat Self-Government is one of the types of entities of the main territorial division of the state (Eng. county).

6 Consolidated text, Journal of Laws of 2019, item 512, as amended. The Voivodeship Self-Government is one of the types of entities of the main territorial division of the state (Eng. province).

7 Consolidated text, Journal of Laws of 2018, item 1817.

8 No. 128/2000 Collection of Laws, as amended.

9 No. 129/2000 Collection of Laws, as amended.

10 No. 131/2000 Collection of Laws, as amended. 
\& Skoczylas, 2004, p. 148; Zimmermann, 2005, p. 211; Niewiadomski, Cieślak, Lipowicz \& Szpor, 2009, p. 135; Ura, 2010, p. 196-197; Sládeček, 2013, pp. 310-333). Pursuant to Art. 6 of the Act on Commune Self-Government, the scope of activity of a commune includes all public matters of local importance, not reserved by statute for other entities. In the Czech Republic, communes are obliged to ensure the general development of their territory and satisfy the needs of their citizens, while at the same time protecting the public interest (Art. 2/2 of the Act on Communes). The communes' own tasks and competencies include matters under the regulation of separate laws, and matters which are in the interest of the commune, unless they are entrusted by law to regions, ascribed to commune bodies within the scope of state administration, or performed directly by state administration bodies, i.e., administrative authorities (Art. 35/1 of the Act on Communes).

In relation to foreigners, Art. 37 of the Polish Constitution formulates the principle that anyone under the authority of the Polish State shall enjoy the freedoms and rights ensured by the Constitution, while exemptions from this principle shall be specified by statute. This is the so-called principle of universality, which is closely connected with human dignity (Safjan \& Bosek, 2016, p. 910; Garlicki \& Zubik, 2016, p. 182). Similarly, according to Art. 42/2 of the Czech Charter of Fundamental Rights and Freedoms, foreign nationals in the Czech Republic enjoy human rights and fundamental freedoms guaranteed by the Charter, unless it is expressly stated that they are entitled to citizens only. Guaranteeing the exercise of freedom and the realisation of most of the rights also applies to foreign nationals. Hence, it can be concluded that the local self-government should also perform its tasks with foreign nationals in mind (e.g., whether they are a family, a pupil, a student, in a difficult life situation, unemployed, etc.).

In Poland, a self-government's own tasks include spatial order; real estate management; environmental and nature protection; water management; municipal roads, streets, bridges, squares, and road traffic organization; supporting families and foster care systems; public education; public order, and citizens' safety; fire and flood protection; pro-family policy, including ensuring social, medical and legal care for pregnant women; and cooperation with local and regional communities in other countries. The literature indicates that the tasks of the commune fall into four groups: tasks related to infrastructure, tasks related to social infrastructure, tasks related to public safety and order, and tasks related to spatial and ecological order (Stahl \& Jaworska-Dębska, 2010, p. 274). The acts specify 
which of the commune's own tasks are mandatory. The Act on Commune Self-Government provides that other acts may impose an obligation on a commune to perform delegated tasks within the scope of government administration. In this respect, the guideline specified in the judgment of the Constitutional Tribunal is still valid; providing that the activities of all state bodies should comply with the fundamental principle of a democratic state of law, i.e., within the framework and on the basis of legal provisions ${ }^{11}$ (Dolnicki, 1999, pp. 94-95), which naturally applies to the performed tasks.

In the Czech Republic, according to Art. 35 of the Act on Communes, a commune is engaged in the promotion of social welfare and the satisfaction of the needs of its citizens through the tasks of satisfying housing needs; health protection and promotion; the development of transport and communication; information, education and upbringing needs; overall cultural advancement; and the protection of public order. Apart from its own tasks, it is also concerned with delegated competences within the entrusted state administration.

It is worth noting that in both countries, the legislator does not mention foreign nationals among the tasks of local self-government entities. As Princ (2081, p. 123) noted, in Poland, the status of a foreigner is primarily regulated by three legal acts: the Act of December 12, 2013, on Foreign Nationals (FNA), ${ }^{12}$ The Act of July 14, 2006, on the Entry into, Residence in and Exit from the Territory of the Republic of Poland of Citizens of the Member States of the European Union and their Family Members $^{13}$, and the Act of June 13, 2003, on Granting Protection to Foreign Nationals within the Territory of the Republic of Poland. ${ }^{14}$ Moreover, acts which are mainly related to the acquisition of citizenship; the Act of April 2, 2009, on Polish Citizenship ${ }^{15}$ and the Act of November 9, 2000, on Repatriation, ${ }^{16}$ should also be included in the group of acts mostly related to foreign nationals. In addition, this collection should also include the

11 Resolution of the Constitutional Tribunal of 27.09.1994, ref. no. W 10/93.

12 Consolidated text, Journal of Laws of 2018, item 2094, as amended.

13 Consolidated text, Journal of Laws of 2017, item 900, as amended; hereinafter: the Act on Entry.

${ }^{14}$ Consolidated text, Journal of Laws of 2016, item 1836, as amended; hereinafter: the Act on Protection.

15 Consolidated text, Journal of Laws of 2017, item 1462 as amended.

${ }^{16}$ Consolidated text, Journal of Laws of 2014, item 1392 as amended. 
Act of September 7, 2007, on the Card of the Pole. ${ }^{17}$ In this act, the legislator also very sparingly mentions the role of local self-government units. ${ }^{18}$ A few exceptions are the participation of communes in the reception of repatriates. Tasks related to the integration of foreigners have been entrusted by the legislator to poviats within the framework of an individual integration programme. It must be admitted, however, that pursuant to the Act on Social Assistance of March 12, 2004, ${ }^{19}$ these activities are addressed mainly to foreign nationals who have been granted the refugee status or subsidiary protection, as well as to members of their families.

The most important acts regulating the legal status of foreigners in the Czech Republic are the Act on the Residence of Foreigners in the Territory of the Czech Republic, ${ }^{20}$ followed by the Asylum Act. ${ }^{21}$ However, there are few provisions on the tasks or role of the local self-government in these acts. For example, one of the conditions for granting a temporary residence permit for investment purposes is the intention to carry out a significant investment with a contribution for the state, region, or commune (Art. 42n of the Residence Act). The act further regulates the powers of the police or commune authorities in relation to the organisation of local elections (Art. 158 or Art. 158c of the Residence Act). The commune in which the detention centre for foreigners or an asylum centre is located is entitled to an allowance from the Ministry of the Interior to cover the costs related to the centre within its territory. The Ministry of the Interior can also give a subsidy to such a commune. The amount of the allowance or subsidy is decided by the government (Art. 151 of the Residence Act, Art. 84 of the Asylum Act). The Ministry can also provide a room in the asylum centre to render medical services (Art. 88 of the Asylum Act). A local self-government unit or its organisation can conclude an agreement with the Ministry of the Interior on running support centres for the inte-

17 Consolidated text, Journal of Laws of 2017, item 1459 as amended.

18 It is worth noting that pursuant to Art. 4 of the Act on Foreign Nationals, in matters regulated therein which fall within the competence of a voivode and according to which a voivode is competent to examine an appeal or in which the higher-level body is the Head of the Office for Foreign Nationals, the provision of Art. 20 of the Act dated January 23, 2009, on Voivode and Government Administration in a Voivodeship (Journal of Laws of 2017, item 2234) shall not be applied. In that regard, the voivode cannot, therefore, by agreement, entrust certain matters within its jurisdiction to local self-government units, even if this would be justified on praxeological grounds.

${ }^{19}$ Consolidated text, Journal of Laws of 2019, item 1507, as amended.

${ }^{20}$ No. 326/1999 Collection of Laws, as amended.

${ }^{21}$ No. 325/1999 Collection of Laws, as amended. 
gration of foreigners (Art. 155a from 01.07.2020). Third-category commune offices may act as guardians of unaccompanied foreign minors (Art. 89 of the Asylum Act).

The conclusions that can be drawn from the reading of the regulations mentioned above are that both in the Czech Republic and in Poland, the provisions regulating the tasks do not focus on foreigners. They do not oblige the authorities to undertake actions aimed at integration, or facilitation for foreigners related to not speaking Polish (Princ, 2019, pp. 99-108) or Czech. The decisions on entry, stay, and the obligation to return; granting protection to foreigners; and acquisition of citizenship are concentrated within the decision-making scope of government bodies. The problem of non-inclusion of the local self-government was already mentioned in the literature (see more in Princ \& Narożniak, 2017; Kryska, 2014). It is not a question of depriving central institutions of the possibility of making decisions in this respect, but rather of maintaining proper proportions as described in the literature (Jaworska-Dębska, Olejniczak-Szałowska \& Budzisz, 2019, p. 14).

\section{Membership Categories of Local Self-Government Entities}

Apart from explaining the extent to which communes can act, the key issue of the subject in question is also for whose benefit public tasks are performed. The answer to this question oscillates around the explanation of 4 terms: citizen, foreigner, resident, member of a local self-government unit. This question is related to persons who constitute the personnel foundation of a local self-government unit, i.e., natural persons who have a legally qualified relationship to the territory of that unit (Hendrych et al., 2012, p. 138). Both Polish and Czech legislators assume that a citizen is a person who has acquired citizenship in a primary or secondary manner, whereas the acts on foreign nationals stipulate, that a foreigner is any person who does not have a citizenship (Polish or Czech). Both countries have therefore adopted negative definitions of the term foreigner, which will be further explained in the following sections. The category of foreigner, therefore, refers mainly to the legal status of an individual (Jagielski, 1997, p. 9).

Membership in a local self-government unit is obligatory and results from features such as residence in its territory (Dolnicki, 1999, p. 17). The 
literature stresses that this is a matter of concentrating on life interests (Dolnicki, 1999, p. 53). In Poland, local self-government law refers to a member of a local self-government unit or a resident of a territorial self-government unit (commune, poviat, voivodeship). In the Czech Republic, however, the legislator uses the term citizen of a community. Defining who is a resident of a local self-government unit or a citizen of a community allows to clarify who should be the focus of the activities of the local self-government.

Pursuant to Art. 1/1 of the Polish Act on Commune Self-Government, the inhabitants of a commune form a self-governing community by virtue of law. A member of a self-governing community is therefore a mandatory and inherent part of a public law corporation. But, can a foreign national be a member of a self-governing community? The Act on Commune Self-Government itself does not solve this dilemma (Olejniczak-Szałowska, 1996, p. 4). In light of the examined issue, the importance of proper recognition of permanent residence is enormous because, among others, it determines the exercise of electoral rights (Kisielewicz, 2014, Art. 5).

For some time, the literature was dominated by the view supported by a systemic and teleological interpretation (Olejniczak-Szałowska, 1996, p. 4) that only a person permanently residing in the commune was its member. At the same time, the legislator does not introduce a minimum period of residence in the territory of a given commune as a condition for recognising someone as a commune resident (Olejniczak-Szałowska, 1996, p. 6). According to Art. 5 point 9 of the Electoral Code, the term permanent residence should be combined with living in a specific town/ city at a given address with the intention of permanent residence. Such a definition strictly corresponds to Art. 25 of the Civil Code. The statutory concept of permanent residence consists of two elements: residence in a specific town/city at a given address, and the intention of permanent residence. The cumulative fulfilment of these conditions determines the establishment of the place of permanent residence. According to A. Kisielewicz, "permanence of residence in a given town/city is defined by the concentration of life activity in such a place, for example, related to work or family. In practice, it is difficult to establish the intention of permanent residence, as this is a largely subjective element. However, one cannot only be guided by the statements made by the person concerned but external circumstances which may indicate that the person concerned really intends to reside permanently in that locality must also be taken into account" (Kisielewicz, 2014, Art. 5). The standpoint expressed in the judgment of the Supreme Administrative Court of April 11, 2013, where- 
by "the mental component - animus of the intention to reside cannot be assessed solely on the basis of an inner conviction, a positive emotional relation to a given locality, or finally a certain verbal declaration or assurances" is fully accepted. For it to be credible, it must still be expressed in the form of specific verifiable behaviours, which would confirm it. ${ }^{22}$ It is, therefore, not enough to make a declaration, but the declaration has to be accompanied by the daily factual and legal acts that will be its expression. Animus must, therefore, be sufficiently externalised in the form of certain behaviours, in particular legal acts (administrative, labour, of civil and family law) Kostrzewska \& Jagodziński, 2015). ${ }^{23}$ The dilemma in this respect is not solved by the institution of the residence registration, because it does not determine the place of residence within the meaning of civil law, but is only a factor facilitating the assessment of the existence of the premises of Art. 25 of the Civil Code. ${ }^{24}$ On the other hand, it can be assumed that there is a presumption in the legal system that a natural person is residing in the place where $\mathrm{s} / \mathrm{he}$ is registered for permanent residence (Janowicz, 1999, p.115; Adamiak \& Borkowski, 2005, p. 151). There is no doubt that the jurisprudence of courts fully accepts the standpoint that the place of permanent residence is not the place where a person is registered but "where s/he performs his/her basic life functions on a permanent basis, i.e., in particular, s/he lives, eats, sleeps, rests, stores his/her belongings necessary for everyday life (clothes, food, furniture), meets others". ${ }^{25}$ Thus, "a residence is a permanent stay of persons there living only when it is the sole centre of life for them, i.e., premises in which everyday matters are concentrated, where these persons live, rest, run a household, nearby which the registered person tries to concentrate his or her work or study" ${ }^{26} \mathrm{~A}$ permanent stay is a question of fact, and its

22 Compare the judgment of the Voivodship Administrative Court in Bydgoszcz of September 8, 2009, ref. no. I SA/Bd 479/09, Lex no. 525680.

${ }^{23}$ Ref. no. II OSK 530/13, http://orzeczenia.nsa.gov.pl/doc/A03981ADA5

24 Judgement of the Voivodeship Administrative Court in Kielce of November 22, 2012, ref. no. II SA/Ke 636/12, http://orzeczenia.nsa.gov.pl/doc/AD63151CB4. Compare the judgment of the Supreme Administrative Court there quoted of May 7, 2003, ref. no. I SA $228 / 03$.

25 The judgment of the Voivodeship Administrative Court in Kielce of November 22, 2012, ref. no. II SA/Ke 636/12, http://orzeczenia.nsa.gov.pl/doc/AD63151CB4. See also the judgment of the Voivodeship Administrative Court in Cracow of December 8, 2010, ref. no. III SA/Kr 269/10, Lex no. 756922.

${ }^{26}$ Ibid. See also the judgment of the Voivodeship Administrative Court in Poznań of September 29, 2010, ref. no. IV SA/Po 907/09, Lex no. 758636, and the judgment of the 
establishment depends on the individual circumstances of a case. ${ }^{27}$ The provisions of legislation relating to the coordination of social security benefits in the EU can be of great help. According to Art. 1 letter (j) of the Regulation (EC) no. 883/2004 of the European Parliament and of the Council of April 29, 2004, on the coordination of social security systems, ${ }^{28}$ residence means the place where a person habitually resides. While pursuant to the Regulation (EC) no. 987/2009 of the European Parliament and of the Council of September 16, 2009, laying down the procedure for implementing the Regulation (EC) no. 883/2004 on the coordination of social security systems: ${ }^{29}$ "Member States should cooperate in order to establish the place of residence of persons, ... and in the event of a dispute, they should take into account all relevant criteria in order to resolve the matter. They may include the criteria referred to in the relevant articles of this Regulation".

Among other things, the Regulation allows for establishing the centre of life interests of the person concerned on the basis of an overall assessment of all available information relating to the relevant circumstances, which may include (Art. 11/1) the duration and continuity of presence in the territory of the Member States concerned; the person's situation, including the nature and the specific characteristics of any activity pursued; their family status and family ties, the exercise of any non-remunerated activity; and their housing situation. In accordance with clause 2, only where the consideration of the various criteria based on relevant facts as set out above does not lead to an agreement between the institutions concerned, the person's intention, as it appears from such facts and circumstances, especially the reasons that led the person to move, shall be considered to be decisive for establishing that person's actual place of residence.

It should be emphasized that the issue of the length of residence is not addressed in the Act on Commune Self-Government. In the light of current regulations, an opinion may be proposed that a commune resident is not only a person permanently residing in its area, but also another person who concentrates their life interests in a given commune. However, the legal situation of a permanently residing person (who may elect and be

Voivodeship Administrative Court in Warsaw of July 21, 2010, ref. no. IV SA/Wa 279/10, Lex no. 694499).

27 Resolution of the Constitutional Tribunal of August 21, 1991, ref. no. W. 7/91 (Journal of Laws of 1991, no. 81, item 364).

28 OJ L 166, 30.4.2004, p. 1-123.

${ }^{29}$ OJ L 284, 30.10.2009, p. 1-42. 
elected to the authorities, exercise certain rights, like the right to social premises), or a citizen of the Republic of Poland permanently residing in a commune is different. Therefore, it should be considered that not only is a foreigner who is permanently staying in the territory of the Republic of Poland (Kumela-Romańska, 2007, p. 42) a member of the self-governing community, but in consequence, the performance of commune tasks should involve foreigners.

The term citizen is used in the Constitution of the Czech Republic in the sense of national citizenship. This conclusion also results from the Charter of Fundamental Rights and Freedoms, which is part of the constitutional order of the Czech Republic (Art. 3 of the Constitution of the Czech Republic). Wherever the constitutional order uses the term citizen, it is to be understood as referring to a citizen of the Czech Republic (Art. 42/1 of the Charter). The constitutional order clearly differentiates between a citizen and a foreign citizen (every human who does not have a citizenship of the Czech Republic).

According to the Act on Communes, a citizen of a commune is a citizen of the Czech Republic who has permanent residence in the commune, city, or the capital city of Prague (Art. 16 of the Act on Communes). Certain rights of a commune's citizen are also possessed by a citizen of another state who has permanent residence in such a commune, city or the capital city of Prague, and who is granted this right by a published international agreement being binding for the Czech Republic (Art. 17 of the Act on Communes).

At this point, it should be noted, however, that according to the Constitutional Court in electoral matters, the concept of permanent residence should be understood through material terms. Members of the representative body are elected in a secret ballot on the basis of universal, equal, and direct electoral right, and local self-government units are territorial communities of citizens who have the right to self-government (Art. 102/1 and Art. 100/1 of the Constitution of the Czech Republic). Therefore, according to the Court, the right to establish self-government bodies is conditioned by the actual bond between the citizen (voter) and the commune. ${ }^{30}$

The issue of local elections is an excellent illustration of this. A few weeks before the elections to the representative bodies of communes took place NALUS

30 See the judgment of the Constitutional Court of May 4, 2011, ref. no. Pl.ÚS 6/11, 
in the Czech Republic in 2014, a citizen of the Slovak Republic, P.N., and a citizen of the Republic of Poland, K.K.S., with temporary EU citizen residence in the territory of the Czech Republic (registered stay of more than three months and not permanent residence) addressed the court because the commune authorities rejected their requests to enter them as a supplement to the permanent electoral roll of EU Member State nationals who wish to exercise their right to vote in the elections to the commune representative bodies.

The applicants invoked the Treaty on the Functioning of the European Union (TFEU), according to which EU citizens have the right to vote and to stand as a candidate in elections to the European Parliament and in local elections in the Member State of their residence under the same conditions as nationals of that State. ${ }^{31}$ According to the applicants, neither the TFEU nor Council Directive 94/80/EC clearly state how long a Member State is to be the place of residence of a national of another Member State in order for them to exercise the right to vote. The starting point of the Directive is, as the applicants claim, the principle of non-discrimination of nationals of other Member States. ${ }^{32}$ According to the applicants, the condition of permanent residence established by the national electoral law, which provides for the exercise of the right to vote and stand as a candidate in elections to the representative bodies of communes both for Czech citizens and for citizens of other EU Member States, is only apparently compliant and non-discriminatory. Permanent residence of Czech citizens should be understood here only as permanent recorded residence within the meaning of the Act on Residential Records. In the case of nationals of other Member States, permanent residence is to be understood as a permanent residence permit within the meaning of the Act on the Residence of Foreigners in the territory of the Czech Republic. In the opinion of the applicants, this stay is not only of a recorded nature, but it is one of the types of residence permits for foreigners that can be obtained only after several years of residence in the country. Such

31 Art. 20/2 letter b and Art. 22 of the consolidated version of the TFEU (Official Journal No. 2010/C 83/01). Council Directive 93/109/EC of 6 December 6, 1993, laying down detailed arrangements for the exercise of the right to vote and to stand as a candidate in elections to the European Parliament for citizens of the Union residing in a Member State of which they are not nationals; and Council Directive 94/80/EC of December 19, 1994, laying down detailed arrangements for the exercise of the right to vote and to stand as a candidate in municipal elections for citizens of the Union residing in a Member State of which they are not nationals.

32 Art. 4 of Council Directive 94/80/EC. 
national law, according to the applicants, constitutes incompatibility both with the TFEU and the provisions of Directive 94/80/EC. In the opinion of the applicants, in accordance with Directive 2004/38/EC of the European Parliament and of the Council, ${ }^{33}$ the condition of residence in the Czech Republic must be considered as fulfilled at least for those persons who have the right of residence in accordance with Art. 8 of that Directive and have received a confirmation of temporary residence pursuant to the national migration law. These foreigners may, in the opinion of the applicants, demand the right to vote.

The courts accepted the motions of the applicants, and in both cases they were entered as a supplement to the permanent electoral roll kept by the commune council in their place of residence (temporary residence). ${ }^{34}$ The Regional Court of Brno concluded that pursuant to Art. 20/1 and 2 of the TFEU, and Art. 3 and 4/1 and 3 of Council Directive 94/80/EC, EU citizens have the right to vote and to stand as candidates in local elections in the Member State in which they have a place of residence under the same conditions as nationals of that State. According to the Court, the provisions of the Treaty and the Directive set forth the right to vote for nationals of other Member States, which is dependent on the place of residence, whereas the Czech electoral law places the condition of registration for permanent residence. As far as the Court is concerned, it may be concluded from the TFEU that for a national of another Member State, the law cannot impose conditions to exercise the right to vote which are different from those imposed on Czech nationals. The Court pointed out that Czech law imposes the same condition on Czech nationals and nationals of other Member States to exercise the right to vote and to stand as a candidate in elections, namely on the registration for permanent residence. In the opinion of the Court, the data on the permanent residence of Czech citizens pursuant to the Act on the Residential Records primarily serves a record-keeping function, or to ensure accessibility, availability, and control, whereas permanent residence of nationals of other Member States in the Czech Republic is regulated by the migration law. A comparison of the regulations on the permanent residence of Czech and EU citi-

33 Directive 2004/38/EC of the European Parliament and of the Council of April 29, 2004 , on the right of citizens of the Union and their family members to move and reside freely within the territory of the Member States.

34 The Ruling of the Regional Court in Brno of September 19, 2014, ref. no. 64 A 6/2014; and the ruling of the Regional Court in Prague of September 22, 2014, ref. no. 50 A 21/2014. See also Ondřejek \& Ondřejková, 2015. 
zens shows, according to the Court, that these are two completely incomparable categories since, in order to obtain a permanent residence permit, an EU citizen must fulfil much stricter conditions than a Czech citizen (especially since in most cases the condition is long-term residence in the Czech Republic). In the Court's opinion, the electoral law regulations do not treat permanent residence or a permanent residence permit as a matter of records. According to the Court, the TFEU or Council Directive 94/80/EC have not been adequately transposed into Czech domestic law, since the electoral law imposes different conditions on nationals of Member States and on Czech nationals. The condition for permanent residence of a national of another Member State is discriminatory, and therefore it cannot be taken into account in this case. For the Court, it was not possible to make use of the indirect effect of European Union law in the case of cited European provisions, and thus it was necessary for the Treaty and the Directive to have a direct effect on a person since the fundamental conditions for the application of such effect were met. As a result, the applicant has the right to vote and, therefore, upon the motion, they have the right to be entered as a supplement to the permanent electoral roll in the elections to the representative bodies of the communes.

After the issuance of this ruling, the National Electoral Commission recommended that in the October elections to the representative bodies of communes in 2014, there should be a possibility to include EU citizens with temporary residence in the supplement to the permanent electoral roll. ${ }^{35}$ Although the ruling of the Regional Court in Brno was issued in a specific case, it confirmed the voting right of more than one hundred thousand citizens of other Member States with temporary registered residence in the territory of the Czech Republic.

As a result of the ruling, the term citizen of a commune had to be redefined and include nationals of other Member States residing in the commune (and in the light of current judicature, also those nationals of other Member States with temporary registered residence in the territory of a commune), since, in the opinion of the Constitutional Court, a citizen of a commune should be interpreted pro-EU, with reference to Art. 20/1 of the TFEU, in order to guarantee their active participation in the works of the commune self-government. ${ }^{36}$

35 See http://www.mvcr.cz/clanek/volit-ve-volbach-do-zastupitelstev-obci-mohou-iobcane-eu-s-prechodnym-pobytem.aspx.

36 See the judgment of the Constitutional Court of April 19, 2010 , ref. no. IV. ÚS 1403/09, NALUS. 
The commune is a society not only in the sociological but also in the legal sense. The question of who is a member of a local self-government unit depends on relevant legal regulations of the country concerned, which do not have to take into account other aspects, such as the psychological attitude of certain persons towards the place in question, the actual situation, etc. (Hendrych et al., 2012, p. 134). It is not just about an abstract question. The answer to this question has further consequences for such processes as participation or decision-making (Dobrić Jambrović, 2015, p. 176). Only a member of the community is a part of the organism of the local self-government and, as such, is one of the holders of the right to local self-government; with the right to participate actively in these processes through actions such as local elections, local referendums, etc.

As in the case of the citizenship of the state, international law requires that there is a genuine connection ${ }^{37}$ between a citizen and a state, thus the authors consider that there must be a genuine connection between the commune and the foreigner, in order for them to be considered a member of a self-governing community. On the other hand, national law where such bonds exist should guarantee an adequate catalogue of the rights of such a foreigner.

In conclusion, the legal situation is the same for foreigners of EU origin. However, the above considerations reveal differences in the understanding of who is a member of the self-governing community. The analysis that was carried out allows for the conclusion that the scope of this term in Poland is broader because the Act on Commune Self-Government applies to foreigners regardless of their citizenship. Whereas in the Czech Republic, only Czech or EU citizens can be a citizen of a commune. In the opinion of the authors, the challenge for both states is to implement provisions allowing for the performance of tasks for all foreigners residing in the territory of the local self-government unit, regardless of the basis of residence.

\section{Examples of Actions Benefiting Foreigners within the Scope of Binding Provisions of Law}

It should be noted that within the scope of general regulations imposing actions for the benefit of the inhabitants, the communes undertake vari-

37 See Liechtenstein vs. Guatemala - Nottebohm - Judgement of April 6, 1955 - Second Phase - Judgements [1955] ICJ 1; ICJ Reports 1955, p. 4; [1955] ICJ Rep 4 (6 April 1955). 
ous steps. An example of actions undertaken for the benefit of foreigners is the Gdańsk Model of Immigrant Integration program adopted by councillors. ${ }^{38}$ The legal basis for this program became the Social Welfare Act, which provides, among its own tasks, the undertaking of other activities resulting from discerned needs, including the development and implementation of protection programs. The leading idea of the Act, within such a generally specified task, is that foreigners are part of a local self-government unit. According to the resolution, the Model of Immigrant Integration defines the areas and directions of activities aimed at conducting an effective and efficient policy of the City of Gdańsk concerning the integration of immigrants, including guidelines and recommendations for its implementation. The team preparing the integration model defined that the main objective is to strengthen the integration of immigrants in the following areas: education, culture, social assistance, housing, combating violence and discrimination, local communities, employment, and health.

Other Polish cities (communes) also perceive the need to support foreigners. An example is the functioning of entities such as the Migrant Info Point in Poznań, whose aim is to assist foreigners in dealing with official matters, legalising their stay, as well as organising workshops, language courses, training, and integration meetings. This is an example of the privatisation of public tasks because the foundation of the Migration Research Centre receives financial support for the organization of projects within the local self-government subsidies (the city of Poznań).

Very interesting experiences come from another city, Sopot, where the City Council wanted to provide shelter to foreigners. The intention of the local authorities was to provide shelter for orphans from Syrian Aleppo. It is worth noting that the communes do not have competence in granting international protection (Princ \& Narożniak, 2017, pp. 211-226). This is a task that is concentrated within the framework of government objectives. Unfortunately, the activity of the commune in this matter did not bring positive results due to the opposition of the government. The attempt however, opened a certain space for discussion. As such, questions arose why local self-government entities cannot enter the process of granting protection to foreigners, why their intentions in this respect are not taken into account by the government, and whether a commune can undertake actions for the benefit of persons who are not yet its residents. The

38 Resolution No. XXVI/673/16 of the City Council of Gdan'sk of June 30, 2016, on the adoption of the Gdan'sk Model of Immigrant Integration. 
issue also revealed a noticeable change in the functioning of some local self-government units, based on aspirations to take part in solving issues previously reserved for the government (state).

Similarly, in the Czech Republic there are examples of local self-government activities in favour of foreigners related mainly to their integration. The literature on the subject in question, however, also indicates the criticism that, in the beginning, local self-government units were not sufficiently involved in the governmental concept of foreigners' integration. These activities take time, especially in recent years in which we encounter such phenomena as a regional integration coordinator, advisory bodies, cooperation with NGOs or regional/local projects, or integration concepts (Pořízek, 2018, pp. 56-57).

The Commission of the Council of the Capital City of Prague illustrates that local self-governments notice that they should focus their attention on foreigners residing in the territory of the country. The commune council (rada obce), as well as the Prague City Council, is the executive body of the commune elected by the representative body (zastupitelstvo) from among its members. The council establishes individual commissions, which are considered bodies of the council, i.e., bodies of the authority. However, they are not bodies with independent competence (Prücha, 2011, p. 72).

The permanent Commission of the Prague City Council for the Integration of Foreigners (Komise Rady Hlavního města Praby pro oblast integrace cizincui) should be mentioned in this context. The Commission is an initiating and advisory body of the council for the integration of foreigners staying in the territory of the city/town and concerning their inclusion into the society of the inhabitants and citizens of the city/town. The Commission is responsible for presenting its standings and ideas to the council. Commission members are appointed by the council and are accountable to the council. Members must have a sufficient level of capacity and knowledge of the integration of foreign nationals (Kopecký et al., 2017, pp. 274-276). Among the members of this committee, there are both foreigners and employees of non-governmental organisations dealing with foreigners. ${ }^{39}$ The functioning of such mixed advisory bodies in cities or communes with a significant number of foreigners can be considered one of the European standards for participation at the local level (Musa \& Dobrić Jambrović, 2018, pp. 301-302).

39 See the websites of the Capital City of Prague https://praha.eu. 
Another example is the Community Interest Society (Integračni centrum Praba, o.p.s.) that has been functioning in Prague since March 2012. The founder of this company is the city of Prague, which is also its sole owner. ${ }^{40}$ According to the founding act, the company's aim is to provide generally useful services in the field of rights' protection and to support the integration of foreigners in the territory of the capital city of Prague. The company provides various types of generally useful services such as: providing social counselling aimed at full integration of foreigners residing in the capital city of Prague; providing legal and labour law counselling aimed at foreigners residing in the capital city of Prague, together with issues related to the protection of the fundamental rights of foreigners and the fight against their discrimination; providing educational activities, including, among others, Czech language courses, social and cultural courses for foreigners residing in the territory of the capital city of Prague; securing information and education activities for the public with the aim of supporting the social integration of foreigners residing in the territory of the capital city of Prague; securing social, cultural and sports activities, as a platform for establishing social contacts between foreigners residing in the territory of the capital city of Prague; running contact, advisory and information centres for foreigners residing in the territory of the capital city of Prague; preparing and implementing projects aimed at facilitating the integration of foreigners residing in the territory of the capital city of Prague with the society and the labour market.

The founding act sets forth the conditions for the provision of the aforementioned services of general interest. The company's task is to provide generally useful services in such a way that the legitimate interests of foreigners residing in the territory of the capital city of Prague are supported in every way, with the aim of achieving their full integration within the society, together with a guarantee of equal rights. Generally, useful services may also be rendered against payment, if the grants, subsidies or donations from natural or legal persons obtained for their provision are not sufficient. Paid services must be provided in accordance with a price list approved by the authorised bodies of the company. The price list must be available to the public at the company's registered office in such a way that each user is able to familiarise themselves with it.

40 See data in the commercial register (obchodní rejstřik) https://or.justice.cz (Integrační centrum Praba, o.p.s., IČO 24228320). 
One may conclude from the above considerations that despite the lack of legal regulations concerning tasks, local self-governments, i.e., communes, undertake activities for the benefit of foreigners residing in their territory. They may be related to obligations arising from other acts, e.g., in the field of education law. It should be noted that at present, there are local self-governments that aspire to play a greater role in matters previously reserved for the state, e.g., granting protection to foreigners in the territory of Poland.

\section{Conclusion}

A significant change in the migration situation can be observed in the two compared countries, relating to the fact that both Poland and the Czech Republic have become places of permanent residence. According to our observations of the situation in both countries, the role of local self-government has been growing since the 1990s. It has strengthened its position both in the political system and in the perception of the public. In each of the countries discussed, the local self-government asserts to wider participation in governing the state, to participating in the decision-making process, and to taking responsibility as well. The afore mentioned mainly concerns big cities.

In light of the research, several postulates can be proclaimed. First of all, and what is in line with the main thesis, that drawing near to the point of solving the so-called wicked problems can only take place with the participation and joint responsibility of all authorities (state, regional and local), as well as the society. This observation mainly concerns the granting of international protection (Princ \& Narożniak, 2017, pp. 225-226). Secondly, a difficult migration situation requires multi-level solidarity; the solidarity between the state and local self-governments, and between members of local self-government and migrants. Such a conclusion arises in light of the essence of the wicked problems. Proper cooperation in this area brings an effective immigration policy closer to the point of problem-solving (Giljević \& Lalić Novak, 2018, p. 378, Đordević, 2019, p. 432). In this regard, as the third postulate, one can call for entrusting some tasks related to migration to local self-governments. In particular, it is postulated that communes should participate in some decision-making processes. The lack of appropriate legal regulations is overtaken by political decisions. These decisions are related to a lack of willingness to lose certain competences and control of the immigration process by central authorities. Fourthly, 
it is worth considering whether the time has come for the next decentralisation step and various forms of internal/international and horizontal/ vertical cooperation. Lastly, the authors of the article postulate a change in the understanding of the term member of the self-governing community. Foreigners should have the same rights as the inhabitants of the local self-government community immediately after obtaining their residence, regardless of their length of stay. The concentration of life interests and genuine connections are determined in this respect. Therefore, a number of new tasks of local self-government units should be identified, such as integration, culture, health care, and education. Incidentally, it is of vital importance to consider whether local self-government units can identify the tasks themselves. The basis of residence should determine the scope of entitlements. Deliberations included in this paper allow for the conclusion that while local self-governments may identify new tasks, the competences must always originate from the statutes.

\section{References}

Adamiak, B., \& Borkowski, J. (2005). Kodeks postepowania administracyjnego. Komentarz. [The code of administrative proceedings. Commentary]. Warsaw, Poland: Wydawnictwo C.H. Beck.

Dobrić Jambrović, D. (2015). Implementing open government policies on subnational levels. In International multidisciplinary scientific conferences on social science and arts, SGEM 2015, Volume I Political Sciences - Law (pp. 175-182). Albena, Bulgaria: SGEM, https://doi.org/10.5593/sgemsocial2015/b21/s4.023

Dolnicki, B. (1999). Samorzad terytorialny. Zagadnienia ustrojowe [Local government. Structure issues]. Kraków, Poland: Zakamycze.

Đordević, S. (2019). Local government capacities for the integration of migrants: Good European experiences and practices. In I. Koprić, G. Lalić Novak, \& T. Vukojičić Tomić, Migrations, diversity, integration, and public governance in Europe and beyond. (pp. 427-445). Zagreb, Croatia: Institute for Public Administration.

Filip, J., \& Svatoň, J. (2011). Státověda. [Theory of State]. 5th edition. Prague, Czech Republic: Wolters Kluwer.

Garlicki, L., \& Zubik, M. (Eds.). (2016). Konstytucja Rzeczypospolitej Polskiej. Komentarz [Constitution of the Republic of Poland: Commentary], vol. 1. Warsaw, Poland: Wydawnictwo Sejmowe.

Giljević, T., \& Lalić Novak, G. (2018). Coordination instruments in Croatian integration policy: Classification, evaluation, and proposals for improvements. Croatian and Comparative Public Administration, 18(3), 373-396, https://doi. org/10.31297/hkju.18.3.1 
Hendrych, D., Čebišová, T., Kopecký, M., Mikule, V., Pomahač, R., Prášková, H., Staša, J., \& Vopálka, V. (2012). Správní právo. Obecná část [Administrative Law. General part]. 8th edition. Prague, Czech Republic: C. H. Beck.

Jagielski, J. (1997). Status prawny cudzoziemca w Polsce (problematyka administracyjnoprawna) [Legal status of a foreigner in Poland (Administrative and legal issues)]. Warsaw, Poland: Wydawnictwo prawnicze.

Janowicz, Z. (1999). Kodeks poste powania administracyjnego. Komentarz [The code of administrative proceedings. Commentary]. Warsaw, Poland: Wydawnictwa Prawnicze PWN.

Jaworska-Dębska, B., Olejniczak-Szałowska, E., \& Budzisz, R. (2019). Decentralizacja $i$ centralizacja administracji publicznej. Wspótczesny wymiar w teorii $i$ praktyce [Decentralization and centralization of public administration. The contemporary dimension in theory and practice]. Warsaw-Łódź, Poland: Wydawnictwo Uniwersytetu Łódzkiego.

Kisielewicz, A. (2014). Komentarz do art.5 Kodeksu wyborczego [Commentary on Article 5 of the Electoral Code]. In. K. W. Czaplicki, B. Dauer, S.J. Jaworski, \& F. Rymarz, Kodeks wyborczy. Komentarz [Electoral Code. Commentary]. Warsaw, Poland: Lex, Wolters Kluwer Polska SA.

Kopecký, M. (2010). Právni postaveni obci a krajů. Základy komunálního práva [Legal status of municipalities and regions. The basics of municipal law]. Prague, Czech Republic: Wolters Kluwer.

Kopecký, M., Průcha, P., Havlan, P., \& Janeček, J. (2017). Zákon o obcích. Komentár [Act on municipalities. Commentary]. 3rd edition. Prague, Czech Republic: Wolters Kluwer.

Koprić, I., Lalić Novak, G., \& Vukojičić Tomić, T. (2019). Migrations, diversity, integration, and public governance in Europe and beyond. Zagreb, Croatia: Institute for Public Administration.

Koprić, I. (2018). Suvremeni trendovi u razvoju lokalne samouprave i hrvatska lokalna i regionalna samouprava [Contemporany trends in the development of local self-government and Croatian local and regional self-government]. In Koprić, I. (ed.) Europeizacija brvatske lokalne samouprave. Dva desetljeća primjene standarda Europske povelje o lokalnoj samoupravi [Europeanization of Croatian local self-government. Two decades of the implementation of European charter on local and self-government] (pp. 1-56). Zagreb, Croatia: Institute for Public Administration, https://doi.org/10.1515/eoik-2015-0006

Kostrzewska, J., \& Jagodziński, M. (2015). Miejsce zamieszkania a wygaśnięcie mandatu radnego [Place of residence and the expiry of the councilor's mandate], Prawo dla samorzadu, 18.09.2015. http://prawodlasamorzadu.pl/2015.09.18miejsce-zamieszkania-a-wygasniecie-mandatu-radnego.html\&strona $=2$ [opinion].

Kumela-Roman'ska, M. (2007). Administracyjnoprawny status cudzoziemca - członka wspólnoty samorza dowej [Administrative and legal status of a foreigner - a member of the local government community]. Samorzad terytorialny, 6, 42-50.

Kryska, D. (2014). Vývojové tendence v organizaci státní správy na úseku pobytu cizinců [Trends in government organizations in the area of residence of for- 
eigners]. In V. Sládeček, K. Frumarová, \& P. Melotíková (eds.). Organizace státní správy - vývojové tendence [Government organizations - trends] (pp. 216227). Prague, Czech Republic: Leges.

Leoński, Z. (2004). Nauka administracji [Administrative science]. Warsaw, Poland: Wydawnictwo C. H. Beck.

Leon'ski, Z., Hauser, R., \& Skoczylas, A. (2004). Zarys prawa administracyjnego [Overview of administrative law]. Warsaw, Poland: Wydawnictwo Prawnicze LexisNexis.

Lisowski, P. (2019). Samodzielność w administrowaniu [Independence in administration]. In B. Jaworska-Dębska, E. Olejniczak-Szałowska, \& R. Budzisz (eds.) Decentralizacja i centralizacja administracji publicznej. Wspótczesny wymiar $w$ teorii $i$ praktyce [Decentralization and centralization of public administration. The contemporary dimension in theory and practice] (pp. 89-104). Warsaw-Łódź, Poland: Wydawnictwo Uniwersytetu Łódzkiego.

Musa, A., \& Dobrić Jambrović, D. (2018). Participacija na lokalnoj razini kao standard Vijeća Europe: uloga Europske povelje o lokalnoj samoupravi i Protokola o pravu na sudjelovanje u poslovima lokalnih vlasti. [Participation on local level as Council of Europe's standard: The role of the Euroepan charter of local self-government and the Protocol on Right to Participate in the Affairs of a Local Authority]. In I. Koprić (ed.) Europeizacija brvatske lokalne samouprave. Dva desetljeća primjene standarda Europske povelje o lokalnoj samoupravi [Europeanization of Croatian local self-government. Two decades of the implementation of European charter on local and self-government]. Zagreb, Croatia: Institute for Public Administration, https://doi.org/10.3366/edinburgh/9781474403337.003.0006

Niewiadomski, Z., Cieślak, Z., Lipowicz, I., \& Szpor, G. (2009). Prawo administracyjne [Administrative law]. Warsaw, Poland: LexisNexis Polska.

Olejniczak-Szałowska, E. (1996). Członkostwo wspólnoty samorządowej [Membership of a local government community]. Samorzad Terytorialny, 5, 3-13.

Ondřejek, P., \& Ondřejková, J. (2015). Formation of political community through judicial fiat: An example of EU citizens' voting rights in the Czech Republic. In L. Pítrová (ed.), Rule of law and mechanisms of its protection. Czech perspective (pp. 151-163). Passau-Berlin-Prague: rw\&w Science \& New Media.

Pořízek, P. (2018). "Lesk a bída" integrace cizinců pohledem vládních koncepcí integrace cizinců (s využitím kazuistik z praxe veřejného ochránce práv) [The "Splendors and Miseries" of integration of foreigners from the perspective of the governmental policies for the integration of foreign nationals (In the light of case studies as tested by the public defender of rights)]. Acta Universitatis Carolinae. Iuridica, 2, 49-72, https://doi.org/10.14712/23366478.2018.5

Princ, M. (2018). Mozaika rozwia zan’ prawnych wyznaczaja cych status cudzoziemca [Mosaic of legal provisions determining the status of a foreigner]. In J. Jagielski, \& M. Wierzbowski (eds.) Prawo administracyjne dzis'i jutro [Administrative law today and tomorrow] (pp. 121-131). Warsaw, Poland: Wolters Kluwer.

Princ, M. (2019). Zasada urzędowości języka polskiego a cudzoziemcy [Principle of the official position of the polish language and foreigners]. In A. Kołodziejska, A. Korzeniowska-Polak (eds.) Administracja a zarzadzanie [Ad- 
ministration and management], vol. 20, vol. 3, part 3, (pp. 99-108). Poland, Łodź.

Princ, M., \& Narożniak A. (2017). Relacja pomiędzy administracją rządową a samorządem terytorialnym - uwagi na tle udzielania ochrony międzynarodowej [The relationship between government administration and local government - Comments on the background of granting international protection]. In M. Szewczyk (ed.), Z problematyki prawnej samorzadu terytorialnego. Ksiega dla uczczenia 70. urodzin oraz 45. rocznicy pracy naukowej Profesora Zbigniewa Janku, [Legal issues of local government. Book to celebrate the 70th birthday and 45th anniversary of the scientific work of Professor Zbigniew Janku] (pp. 211-226). Poznań, Poland: Wydawnictwo Naukowe Uniwersytetu im. Adama Mickiewicza, https://doi.org/10.14746/spp.2017.4.20.13

Průcha, P. (2011). Mistní správa [Local Administration]. Brno, Czech Republic: Masarykova univerzita.

Safjan, M., \& Bosek, M. (eds.). (2016). Konstytucja RP. Komentarz do art. 1-86 [Polish Constitution. Commentary on article 1-86], vol. 1. Warsaw, Poland: Wydawnictwo C. H. Beck.

Savino M. (2017). La Risposta Italiana alla Crisi: Un Bilancio [The Italian crisis response: Recap]. In M. Savino, La crisi migratoria tra Italia e Unione europea: Diagnosi e prospettive [The migration crisis between Italy and the European Union: Diagnosis and perspectives]. Napoli, Italy: Editoriale Scientifica.

Sládeček, V. (2013). Obecné správní právo [General administrative law]. 3rd edition. Prague, Czech Republic: Wolters Kluwer.

Sládeček, V. (2019). Obecné správní právo [General administrative law]. 4th edition. Prague, Czech Republic: Wolters Kluwer.

Stahl, M., \& Jaworska-Dębska, B. (Eds.), (2010). Encyklopedia samorzadu terytorialnego [Local government encyclopaedia]. Warsaw, Poland: Difin.

Suchocka, H. (1998). Zasada podziału i równoważenia władzy [The principle of separation and balancing of power]. In W. Sokolewicz (ed.) Zasady podstawowe polskiej Konstytucji [Basic principles of the Polish Constitution] (pp. 146164.). Warsaw, Poland: Wydawnictwo Sejmowe.

Ura, E. (2010). Prawo administracyjne [Administrative law]. Warsaw, Poland: LexisNexis Polska.

Zimmermann, J. (2005). Prawo administracyjne [Administrative law]. Kraków, Poland: Zakamycze.

Ziemski, K. M., \& Karciarz, M. (2019). Zasada decentralizacji ustroju terytorialnego państwa jako wartość w świetle przepisów Konstytucji RP i prawa międzynarodowego [The principle of decentralization of the territorial system of the state as a value in the light of the provisions of the Polish Constitution and international law]. In B. Jaworska-Dębska, E. Olejniczak-Szałowska, \& R. Budzisz (eds.) Decentralizacja $i$ centralizacja administracji publicznej. Wspótczesny wymiar $w$ teorii $i$ praktyce [Decentralization and centralization of public administration. The contemporary dimension in theory and practice] (pp. 131-149). Warsaw, Poland: Wydawnictwo Uniwersytetu Łódzkiego, https:// doi.org/10.15804/ppsy2009023 


\section{Legal sources}

\section{$E U$}

Regulation (EC) No 883/2004 of the European Parliament and of the Council of 29 April 2004 on the coordination of social security systems (Text with relevance for the EEA and for Switzerland) (OJ L 166, 30.4.2004, p. 1-123) [https://eur-lex.europa.eu/legal-content/EN/TXT/?uri=legissum\%3Ac10521].

Regulation (EC) No 987/2009 of the European Parliament and of the Council of 16 September 2009 laying down the procedure for implementing Regulation (EC) No 883/2004 on the coordination of social security systems (Text with relevance for the EEA and for Switzerland) (OJ L 284, 30.10.2009, p. 1-42) [https://eurlex.europa.eu/legal-content/EN/TXT/?uri=CELEX\%3A52016PC0815].

\section{Czech}

https://aplikace.mvcr.cz/sbirka-zakonu/

The Constitution of the Czech Republic, No. 1/1993 Coll., as amended

Asylum Act, No. 326/1999 Collection of Laws, as amended

Act on the Residence of Foreigners in the Territory of the Czech Republic, No. 326/1999 Collection of Laws, as amended

Act on Communes, No. 128/2000 Collection of Laws, as amended

Act on Regions, No. 129/2000 Collection of Laws, as amended

Act on the Capital City of Prague, No. 131/2000 Collection of Laws, as amended

\section{Polish}

Constitution of the Republic of Poland, Journal of Laws of 2019, nb. 78 item 483, as amended [http://prawo.sejm.gov.pl/isap.nsf/download.xsp/ WDU19970780483/U/D19970483Lj.pdf]

Act of March 8, 1990 on Commune Self-Government, Consolidated text, Journal of Laws of 2019, item 506, as amended [http://prawo.sejm.gov.pl/isap.nsf/ download.xsp/WDU19900160095/U/D19900095Lj.pdf]

Act of June 5, 1998 on Poviat Self-Government, Consolidated text, Journal of Laws of 2019, item 511, as amended [http://prawo.sejm.gov.pl/isap.nsf/download.xsp/WDU19980910578/U/D19980578Lj.pdf]

Act of June 5, 1998 on Voivodeship Self-Government, Consolidated text, Journal of Laws of 2019, item 512, as amended [http://prawo.sejm.gov.pl/isap.nsf/ DocDetails.xsp?id=WDU19980910576]

Act of November 9, 2000, on Repatriation, Consolidated text, Journal of Laws of 2014, item 1392 as amended [http://prawo.sejm.gov.pl/isap.nsf/download. xsp/WDU20001061118/U/D20001118Lj.pdf] 
Act of March 15, 2002 on the System of the Capital City of Warsaw, Consolidated text, Journal of Laws of 2018, item 1817 [http://prawo.sejm.gov.pl/isap. nsf/download.xsp/WDU20180001817/O/D20181817.pdf]

Act of June 13, 2003, on Granting Protection to Foreign Nationals within the Territory of the Republic of Poland, Consolidated text, Journal of Laws of 2016, item 1836, as amended [http://prawo.sejm.gov.pl/isap.nsf/download. xsp/WDU20031281176/U/D20031176Lj.pdf]

Act of March 12, 2004 on Social Assistance, Consolidated text, Journal of Laws of 2019, item 1507, as amended [http://prawo.sejm.gov.pl/isap.nsf/download. xsp/WDU20040640593/U/D20040593Lj.pdf]

Act of July 14, 2006, on the Entry into, Residence in and Exit from the Territory of the Republic of Poland of Citizens of the Member States of the European Union and their Family Members, Consolidated text, Journal of Laws of 2017, item 900 [http://prawo.sejm.gov.pl/isap.nsf/DocDetails. xsp?id=WDU20061441043]

Act of September 7, 2007, on the Card of the Pole, Consolidated text, Journal of Laws of 2017, item 1459 as amended [http://prawo.sejm.gov.pl/isap.nsf/ download.xsp/WDU20071801280/U/D20071280Lj.pdf]

Act January 23, 2009, on Voivode and Government Administration in a Voivodeship, Consolidated text, Journal of Laws of 2017, item 2234 [http://prawo. sejm.gov.pl/isap.nsf/DocDetails.xsp?id=WDU20090310206]

Act of April 2, 2009, on Polish Citizenship, Consolidated text, Journal of Laws of 2017, item 1462 as amended [http://prawo.sejm.gov.pl/isap.nsf/DocDetails. xsp?id=WDU20120000161]

Act of December 12, 2013, on Foreign Nationals, Consolidated text, Journal of Laws of 2018, item 2094, as amended [http://prawo.sejm.gov.pl/isap.nsf/ download.xsp/WDU20130001650/U/D20131650Lj.pdf]

Resolution No. XXVI/673/16 of the City Council of Gdańsk of June 30, 2016, on the adoption of the Gdańsk Model of Immigrant Integration [https://www. gdansk.pl/download/2016-07/76356.pdf]. 


\section{LOCAL GOVERNMENT TASKS IN MANAGING MIGRATIONS IN THE CZECH REPUBLIC AND POLAND}

\section{Summary}

Difficult problems that cannot be easily solved, the so-called wicked problems, remain one of the biggest challenges for both Poland and the Czech Republic. They concern both the state authorities and the local self-government. The analysis shows that in both countries, the tasks of local government units, in particular communes, do not focus on foreigners' issues as a separate matter. Despite similar experiences, migration situations, and legal regulations, there are slight differences in both countries with respect to the understanding of who is a member of a local government community, and thus for whom public tasks can be performed. The challenge for both countries is to adjust their legal regulations to focus more on foreigners, primarily in areas such as integration, culture, bealth care, and education. It is also postulated to create the possibility of participation by foreigners in decisions taken by governmental authorities (e.g., in the scope of granting international protection). Undoubtedly, the thesis that solving the "wicked problems" category can only be advanced with the participation and joint responsibility of the local self-government is still very relevant, which was pointed out in the article in several areas. The research results lead to the proposal to recognise a foreigner as a member of the local government immediately after obtaining residence, regardless of the length of stay. The clue is to clearly identify the concentration of life interests and genuine connection, which is determined in this respect.

Keywords: migration, foreigners, local self-government, inhabitants, citizens 


\section{ZADACI LOKALNE SAMOUPRAVE U UPRAVLJANJU MIGRACIJAMA U ČEŠKOJ I POLJSKOJ}

\section{Sažetak}

Jedan od najvećib izazova za državnu upravu i lokalnu samoupravu u Češkoj $i$ Poljskoj ostaju teško rješivi (wicked) problemi. Analiza pokazuje da u obje zemlje pitanja koja se tiču stranaca ne nalaze prikladni odraz u zadacima lokalnih samoupravnib jedinica, napose općina. Slična iskustva, situacije s migracijama $i$ pravna regulacija dovode do manjib razlika u shvaćanjima tko su članovi lokalnih zajednica pa tako i za koga se obavljaju lokalni javni poslovi. Obje zemlje trebaju prilagoditi svoje zakonodavstvo tako da ono uzme u obzir strance ponajprije u područjima integracije, kulture, zdravstvene skrbi i obrazovanja. Treba se osigurati mogućnost sudjelovanja stranaca u javnim odlukama, kao što su one o odobravanju međunarodne zaštite. Nedvojbeno, unaprjeđenje rješavanja teško rješivih problema moguće je samo uz sudjelovanje $i$ zajedničku odgovornost s lokalnom samoupravom, što je u radu istaknuto u više područja. Rezultati istraživanja vode zaključku da je prepoznavanje stranca kao člana lokalne zajednice potrebno odmab po odobravanju boravka neovisno o njegovom trajanju. Ključno je pritom odrediti sve životne interese $i$ stvarnu povezanost stranaca s lokalnom zajednicom.

Ključne riječi: migracije, stranci, lokalna samouprava, stanovnici, državljani 